\title{
The effect of environment on development and survival of pupae of the necrophagous fly Ophyra albuquerquei Lopes (Diptera, Muscidae)
}

\author{
Rodrigo Ferreira Krüger ${ }^{1}$, Lisiane Dilli Wendt ${ }^{2} \&$ Paulo Bretanha Ribeiro ${ }^{1}$
}

12Departamento de Microbiologia e Parasitologia, Universidade Federal de Pelotas, Caixa Postal 354, 96015-710 Pelotas-RS, Brasil.
rodrigo.kruger@ufpel.tche.br; bretanha@ufpel.edu.br
²Programa de Pós-Graduação em Entomologia, Departamento de Entomologia, Instituto Nacional de Pesquisas da Amazônia, Av. André Araújo, 2936.
Caixa Postal: 478, Petrópolis 69011-970 Manaus-AM, Brasil. lisidilli@yahoo.com.br

\begin{abstract}
The effect of environment on development and survival of pupae of the necrophagous fly Ophyra albuquerquei Lopes (Diptera, Muscidae). Species of Ophyra Robineau-Desvoidy, 1830 are found in decomposing bodies, usually in fresh, bloated and decay stages. Ophyra albuquerquei Lopes, for example, can be found in animal carcasses. The influence of environmental factors has not been evaluated in puparia of $O$. albuquerquei. Thus, the focus of this work was motivated by the need for models to predict the development of a necrophagous insect as a function of abiotic factors. Colonies of $O$. albuquerquei were maintained in the laboratory to obtain pupae. On the tenth day of each month 200 pupae, divided equally into 10 glass jars, were exposed to the environment and checked daily for adult emergence of each sample. We concluded that the high survival rate observed suggested that the diets used for rearing the larvae and maintaining the adults were appropriate. Also, the data adjusted to robust generalized linear models and there were no interruptions of $O$. albuquerquei pupae development within the limits of temperatures studied in southern Rio Grande do Sul, given the high survival presented.
\end{abstract}

KEYWORDS. Azeliinae; facultative predator; forensic entomology; garbage flies; Neotropical.

RESUMO. Efeito de fatores ambientais sobre o desenvolvimento e sobrevivência de pupas de Ophyra albuquerquei Lopes (Diptera, Muscidae). Espécies de Ophyra Robineau-Desvoidy, 1830 são encontradas em corpos em decomposição, usualmente nas fases fresca, inchamento e murcha. Entre estas espécies, Ophyra albuquerquei Lopes, 1985 pode ser encontrada em carcaças de ratos e coelhos. A influência de fatores ambientais sobre pupas de O. albuquerquei não tinha sido avaliada até o momento. Desta maneira, o foco deste trabalho foi motivado pela necessidade por modelos de previsão do desenvolvimento de insetos necrófagos em função de fatores abióticos. Colônias de $O$. albuquerquei foram mantidas em laboratório para a obtenção de pupas. Até o décimo dia de cada mês, 200 pupas distribuídas em 10 frascos de vidro foram expostas ao meio e foi verificada diariamente a emergência dos adultos de cada amostra. Os dados se ajustaram a modelos lineares generalizados robustos. Além disto, foi concluído que não existem limiares mínimos e máximos de temperatura para o desenvolvimento de pupas de O. albuquerquei no sul do Rio Grande do Sul, devido à alta sobrevivência apresentada.

PALAVRAS-CHAVE. Azeliinae; Entomologia forense, moscas de lixão; Neotropical; predador facultativo.

The interval of time between the death and the discovery of a corpse is considered the postmortem interval (PMI) and has fundamental importance in investigations of murders and other crimes. This information can help to identify both the criminal and the victim, eliminating suspects and linking the corpse discovered to the missing persons to the PMI estimated (Catts 1990; Geberth 1996).

PMI depends on many factors (Micozzi 1991; Campobasso et al. 2001) and therefore can be extremely difficult to determine (Bass 1984), mainly because of the time-dependence of chemical and physical changes. In PMI longer than three days, the ecological data (Wells \& LaMotte 2010) of necrophagous insect species, mainly flies of the families Calliphoridae, Sarcophagidae and Muscidae, are more robust than traditional methods for determining PMI (Smith 1986).

Temperature is the most important source of variation in the rate of development of immature stages of these flies, and secondarily, humidity and rainfall (Higley \& Haskell 2010).
Temperature changes throughout the day can influence the estimates of PMI, especially when the expert uses models built from constant temperatures (Higley \& Haskell 2010; Krüger et al. 2010). Many studies of fly developmental rates occur at controlled temperatures (Greenberg 1991; Byrd \& Butler 1998; Marchenko 2001; Grassberger \& Reiter 2001), without consideration of variation of temperature and its interaction with other abiotic factors (Tachibana \& Numata 2004; Nabity et al. 2007; Higley \& Haskell 2010). It becomes necessary to consider the influence of factors other than temperature on the development of immature stages of carrion flies in order to generate robust models applied to forensic entomology (Campobasso et al. 2001; Krüger et al. 2010). One of the stages most susceptible to temperature is the pupa, which in most cases occurs in the soil near the corpse (Gomes et al. 2006; Zimmer et al. 2010).

Species of Ophyra Robineau-Desvoidy, 1830 occur in carcasses and corpses in decomposition (Couri et al. 2008; Segura et al. 2009; Rosa et al. 2009; Horenstein et al. 2010; 
Oliveira \& Vasconcelos 2010), usually in the fresh, bloated and decay stages. Ophyra albuquerquei Lopes, 1985 is a species that occur on Brazil and Argentina (Carvalho et al. 2005; Patitucci et al. 2010) and has been found in carcasses of rodents (Moura et al. 1997), rabbits (Souza et al. 2008) and pigs (Barbosa et al. 2009). In these substrates, the larvae may feed in a saprophytic way and also predate on larvae of other flies that are found in these systems (Skidmore 1985).

After feeding, the larvae leave the carcass and begin the pupal stage under the regime of temperature and relative humidity of the soil. The influence of these environmental factors has not been evaluated in puparia of O. albuquerquei. Higley \& Haskell (2010) emphasized obtaining data on the developmental stages of immature necrophagous insect living in different regimes of abiotic conditions.

The objectives of this work were obtaining models to predict the development and survival of a necrophagous insect as a function of abiotic factors for O. albuquerquei pupae.

\section{MATERIAL AND METHODS}

Colonies of $O$. albuquerquei were established from adults caught on a poultry farm on the campus of the Universidade Federal de Pelotas (UFPEL), and maintained in a room with temperature between 22 and $28^{\circ} \mathrm{C}$, with 12 hours photoperiod and 70 to $80 \%$ relative air humidity. The adults were placed in 30x30x30 cm cages and fed a diet containing one part fish meal, two parts milk powder and two parts sugar. Water was provided in a bottle ad libitum. To obtain eggs, vials with culture medium composed of $66 \%$ fish meal, 34\% of sawdust and water were placed inside the cages. The eggs were transferred to containers containing the same diet and placed inside larval rearing funnels. Larvae were maintained to the third-instar stage, when they left the funnel and fell into another container containing damp sawdust as recommended by Hogsette (1996) for Musca domestica Linnaeus, 1758 (Diptera, Muscidae) and $O$. aenescens (Wiedemann, 1830). The post feeding larvae were transferred to glass containers and kept until adult emergence for the replacement of the cages.

Two thousand four hundred 24 hour-old pupae (white puparium - see Fraenkel \& Bhaskaran 1973) were randomly selected from rearing containers for the experiment. The exposition occurred on the tenth day of each month between June 2002 and May 2003. Each month we used 200 pupae distributed in 10 glass jars. The pupae were buried in sawdust and the glass jar was covered with organza. The ten glass jars were exposed in an area with secondary vegetation in an open box laterally, 1.5 meters of soil. The box was stored in shade, protected from rain, and located on the UFPEL campus ( $\left.31^{\circ} 45^{\prime} 48^{\prime \prime} \mathrm{S} ; 52^{\circ} 29^{\prime} 02^{\prime \prime} \mathrm{W}\right)$ and checked daily for adult emergence of each sample until the sixtieth day after exposure or until the emergence of all adults.

Data related to mean daily temperature; relative air humidity and rainfall were obtained daily from the Climatological Station of Pelotas from the Brazilian Agricultural Research Corporation (EMBRAPA - Temperate Climate).
The development time (D) of species, measured in days, was transformed to development rate (1/D). The influence of $\mathrm{mt}$ (mean daily temperature), rh (relative air humidity) and vp (rainfall) on pupal development rate (explanatory variable) was assessed according to linear model (LM) with F distribution and between the months by ANOVA with distribution $\mathrm{F}$.

The influence of $\mathrm{mt}$ (mean daily temperature), rh (relative air humidity) and vp (rainfall) on pupal survival (explanatory variable) was assessed according to generalized linear models (GLM) with quasibinomial proportional distribution of errors to correct over dispersed data (Crawley 2007).

All tests were performed in R statistical software (R Development Core Team 2009), and the level of significance used was $\mathrm{p}<0.05$.

\section{RESULTS}

The temperature (mt, Fig. 1A), relative air humidity (rh, Fig. 1B) and rainfall (vp, Fig. 1C) varied over the months of the trial and influenced the development rate (rate) of pupae of $O$. albuquerquei $\left(\mathrm{F}_{3,107}=328.32, \mathrm{p}<0.001, \mathrm{r}^{2}=0.899\right.$, Fig $2)$. The influence of these factors determined the model: rate $=-0.202+(0.005326 \times \mathrm{mt})+(0.002196 \times \mathrm{rh})-(0.000209$ $\times \mathrm{vp})$.
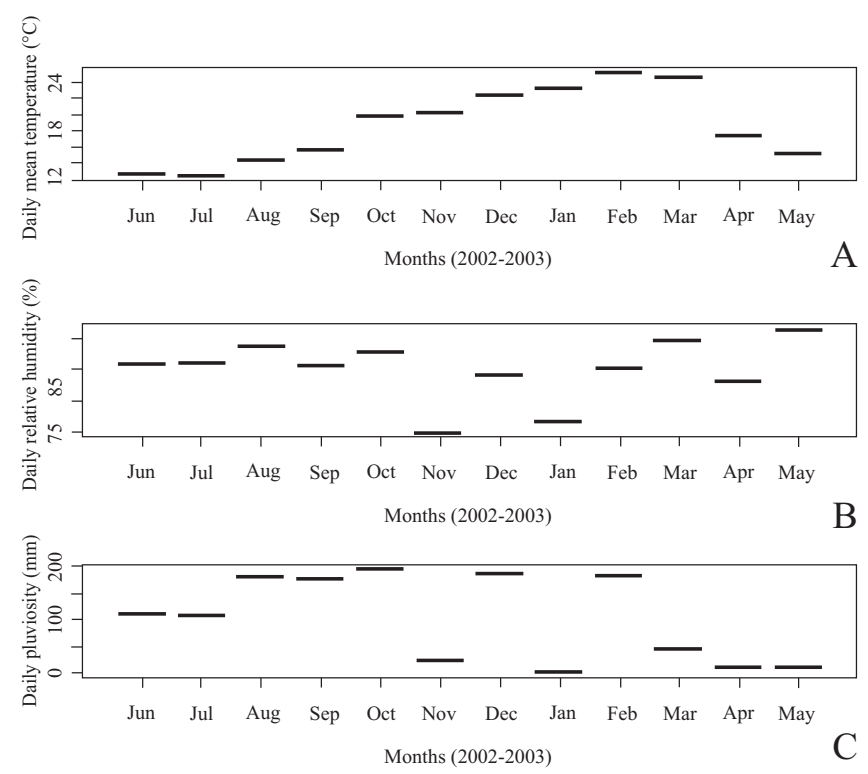

Fig. 1. Average daily temperature (A), average relative air humidity (B) and average daily rainfall (C) between June 2002 (a) and May 2003 (1) in the environment.

In this model, considering the adjusted regression coefficient $\left(\mathrm{r}^{2}{ }_{\text {adj }}\right)$, the temperature explains $56.61 \%$ of the variation of the data related to development rate (rate); $22.69 \%$ rainfall and relative humidity less than $10 \%$. By adding the rainfall, the model increases the adjusted $\mathrm{r}^{2}$ from.56 to.79. Including further a variable rh, the model explains over $10 \%$. 
The rate of development varied between months $\left(\mathrm{F}_{11,99}=\right.$ 596.47, p < 0.001) (Fig. 2) and survival was not influenced by the average daily temperature, daily mean relative air humidity and mean daily rainfall $\left(\chi^{2}=193.78, \mathrm{p}=0.069\right)$ and ranged from $85 \%$ to $99 \%$ between the months (Fig. 3 ).

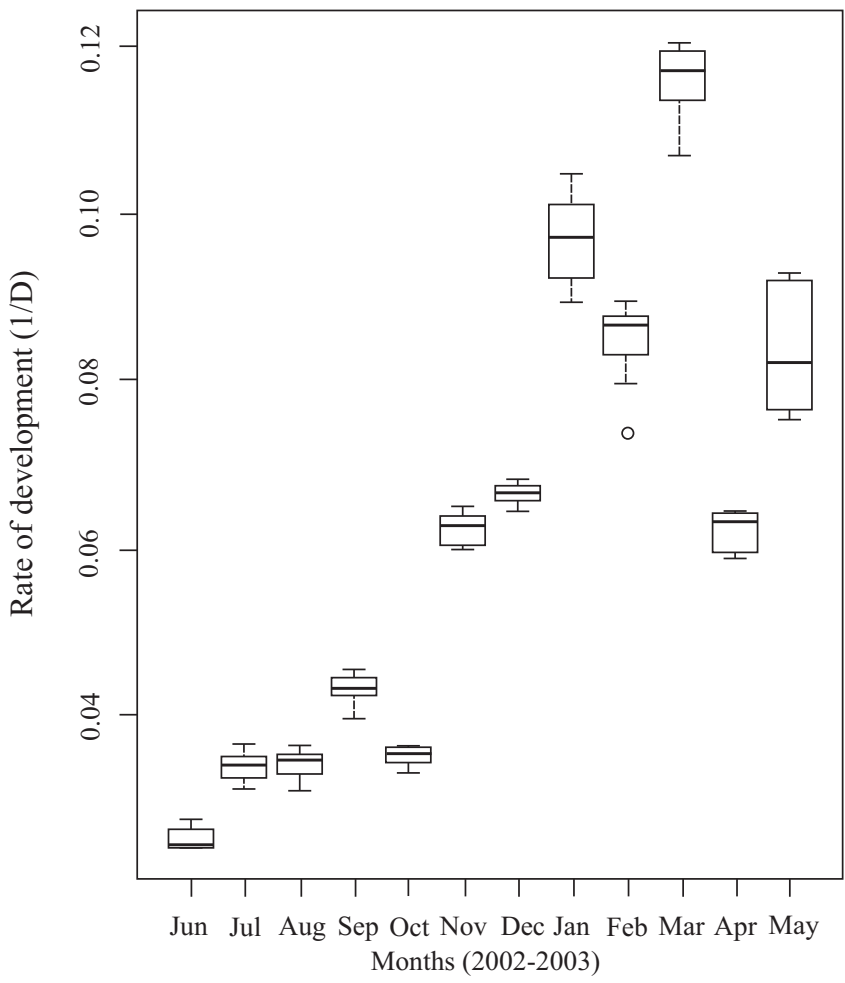

Fig. 2. Mean, standard deviation and error rate of development from June 2002 to May 2003

\section{DISCUSSION}

According to the model obtained and the values in Figure 1 , we observed that the deviations were larger among the observed and estimated values in late autumn and in winter, probably because of the curvilinear behavior that the rate of development of insect assumes as a function of temperature when approaching some of its extremes (Ikemoto \& Takai 2000; Byrd \& Castner 2001; Higley \& Haskell 2010).

This pattern of relationship between the rate of development of pupae and the evaluated abiotic factors was previously noted for other species of Ophyra that develop in decaying organic animal matter (Ribeiro et al. 2001; Lefebvre $\&$ Pasquerault 2004). The main difference in respect to other studies is the importance of relative humidity and rainfall for the development of pupae of $O$. albuquerquei. The influence of rainfall was $23 \%$ in explaining the model, which maximizes the rate of development, while relative humidity explains only about $10 \%$ of the variation found.

The relative humidity will interact with temperature to control the evaporation rate of the insect body. In March oc- curred a combination of high temperature and relative humidity with low rainfall (Fig. 1), which increased the rate of development (Fig. 2) and did not affect the survival of pupae (Fig. 3). In contrast, when the relative humidity decreases and the temperature is high as in January (Fig. 1), the rate of development of pupae decreased (Fig. 2), with the lowest survival rates (Fig. 3).

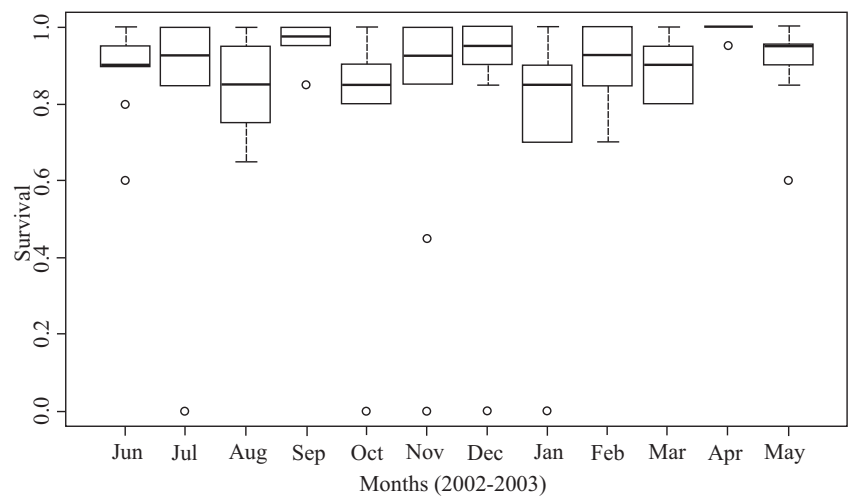

Fig. 3. Average error and standard deviation of the survival between the June 2002 and May 2003.

The range of factors throughout the year and subsequent interaction of these variables (Fig. 1) increase the variation of rate development (Fig. 2). This has direct implication in the analysis of development data as observed by Ikemoto \& Takai (2000) and Richards \& Villet (2008). Richards \& Villet (2008) call attention to the variation of the thermal constant, necessary to estimate the ADD. This estimate may vary depending on the development measures minimum and maximum. This study considered the means of development of pupae per vial, and the variation was not significant between the vials exposed to the same month, but between the months. Therefore, it is more likely that the variation has been caused by the interaction of factors or by the physiology of individuals at minimum and maximum temperatures.

The data imply that temperatures below $15^{\circ} \mathrm{C}$ are not limiting to the development and survival of pupae of species of Ophyra, and that perhaps the populations of these species are able to resist environmental adversity at this stage. According to Costa et al. (2000) and Ribeiro et al. (2000c), this temperature would be limiting for the maintenance of populations of $O$. aenescens because of the low probability of capture of adults in the environment. This finding cannot be taken as evidence of the absence of populations of these species, since the pupae can survive and develop in winter temperatures, including laboratory data that confirm this for $O$. aenescens (Ribeiro et al. 2000a, 2000b, 2001; Lefebvre \& Pasquerault 2004).

Another point is that the $O$. albuquerquei is greater than O. aenescens (RF Krüger data not published) and because it has higher rate of development (Krüger et al. 2003). In consequence, the accumulation of fat is greater in the puparia of 
O. albuquerquei than $O$. aenescens, providing more thermal insulation. Moreover, the period of greatest development is influenced by more ranges of temperature favoring development at low temperatures.

Interestingly, the temperature variation over the year did not influence the survival of pupae of $O$. albuquerquei, as expected. The variation of this factor in the laboratory alters the survival of specimens of other necrophagous flies such as $O$. aenescens (Ribeiro et al. 2000a, 2000b). The results demonstrated the adaptive capacity of $O$. albuquerquei to this region, thus reiterating its forensic importance to southern South America (Moura et al. 1997; Souza et al. 2008; Patitucci et al. 2010).

We concluded that the high survival rate observed suggested that the diets used for rearing the O. albuquerquei were appropriate. Another conclusion is that it was possible to adjust the data to robust generalized linear models because the temperature limits in southern Rio Grande do Sul did not disrupt the development of this species.

\section{ACKNOWLEDGMENTS}

We are grateful to Fundação de Amparo à Pesquisa do Estado do Rio Grande do Sul (FAPERGS - Case No. 0223/2004) for a scientific initiation fellowship granted to LDW. We thank Phil Scholl for English language revision and Juliano L. P. Duarte and Nestor Centeno (UNQ-Argentina) for discussion.

\section{REFERENCES}

Barbosa, R. R.; R. P. Mello; M. M. C. Queiroz \& C. A. Mello-Patiu. 2009. New records of calyptrate dipterans (Fanniidae, Muscidae and Sarcophagidae) associated with the decomposition of domestic pigs in Brazil. Memórias do Instituto Oswaldo Cruz 104: 923-926.

Bass, W. M. 1984. Time interval since death: a difficult decision, p. 136147. In: Rathbun, T. A. \& J. E. Buikstra (Eds.). Human identification: case studies in forensic anthropology. Springfield, Charles C. Thomas, $435 \mathrm{p}$.

Byrd, J. H. \& J. F. Butler. 1998. Effects of temperature on Sarcophaga haemorrhoidalis (Diptera: Sarcophagidae) development. Journal of Medical Entomology 35: 694-698.

Byrd, J. H. \& J. L. Castner. 2001. Forensic Entomology: The utility of arthropods in legal investigations. 1st edition, Boca Raton, CRC Press, $418 \mathrm{p}$.

Campobasso, C. P. G.; D. Vella \& F. Introna. 2001. Factors affecting decomposition and Diptera colonization. Forensic Science International 120: $18-27$.

Carvalho, C. J. B. de; M. S. Couri; A. C. Pont; D. Pamplona \& S. M. Lopes. 2005. A Catalogue of the Muscidae (Diptera) of the Neotropical Region. Zootaxa 860: 1-282.

Catts, E. P. 1990. Analyzing entomological data, p. 124 - 137. In: Catts, E. P. \& N. H. Haskell (Eds.). Entomology and Death: A Procedural Guide. Clemson, Joyce's Print Shop, 182 p.

Costa, P. R. P.; R. L. Franz \& P. B Ribeiro. 2000. Synanthropy of Ophyra spp. (Diptera, Muscidae) in Pelotas, RS, Brazil. Revista Brasileira de Parasitologia Veterinária 9: 165-168.

Couri, M. S.; A. M. Cunha; S. M. F. M. de Souza \& M. Laeta. 2008. Ophyra capensis (Wiedemann) (Diiptera, Muscidae) found inside the esophagus of a mummy in Lisbon (Portugal). Papéis Avulsos de Zoologia 49: 87-91.

Crawley, M. J. 2007. The R Book. New York, John Wiley, 942 p.
Fraenkel, G. \& G. Bhaskaram. 1973. Pupariation and pupation in Cyclorrhaphous flies (Diptera): terminology and interpretation. Annals of the Entomological Society of America 66: 418-422.

Geberth, V. 1996. Practical Homicide Investigation: Tactics, Procedures, and Forensic Techniques. 3rd edition, Boca Raton, CRC Press, 999 p.

Gomes, L.; W. A. C. Godoy \& J. C. Von Zuben. 2006. A review of postfeeding larval dispersal in blowflies: implications for forensic entomology. Naturwissenschaften 93: 207-215.

Grassberger, M. \& C. Reiter. 2001. Effect of temperature on Lucilia sericata (Diptera: Calliphoridae) development with special reference to the isomegalen- and isomorphen-diagram. Forensic Science International 120: $32-36$.

Greenberg, B. 1991. Flies as forensic indicators. Journal of Medical Entomology 28: 565-577.

Higley, L. G. \& N. H. Haskell. 2010. Insect development and forensic entomology, p. 389-406. In: J. H. Byrd \& J. L. Castner (Eds.). Forensic Entomology: The Utility of Arthropods in Legal Investigations. Boca Raton, CRC Press, 681 p.

Hogsette, J. A. 1996. Development of house flies, Musca domestica L., in sand containing varying amounts of manure solids and moisture. Journal of Economic Entomology 89: 940-945.

Horenstein, M. B.; A. X. Linhares; B. R. de Ferradas \& D. Gracía. 2010. Decomposition and dipteran succession in pig carrion in central Argentina: ecological aspects and their importance in forensic. Medical and Veterinary Entomology 24: 16-25.

Ikemoto, T. \& K. Takai. 2000. A new linearized formula for the law of total effective temperature and the evaluation of line-fitting methods with both variables subject to error. Environmental Entomology 29: 671-682.

Krüger, R. F.; P. B. Ribeiro \& C. J. B. de Carvalho. 2003. Desenvolvimento de Ophyra albuquerquei Lopes (Diptera, Muscidae) em condições de laboratório. Revista Brasileira de Entomologia 47: 643 - 648.

Krüger, R. F.; F. D. Kirst \& A. S. B. Souza. 2010. Rate of development of forensically-important Diptera in southern Brazil. Revista Brasileira de Entomologia 54: 624-629.

Lefebvre, F. \& T. Pasquerault. 2004. Temperature-dependent development of Ophyra aenescens (Wiedemann, 1830) and Ophyra capensis (Wiedemann, 1818) (Diptera Muscidae). Forensic Science International 139: 75-79.

Marchenko, M. I. 2001. Medicolegal relevance of cadaver entomofauna for the determination of time of death. Forensic Science International 120: 89-109.

Micozzi M. S. 1991. Postmortem Change in Human and Animal Remains: a Systematic Approach. Springfield, CC Thomas, 124 p.

Moura, M. O.; C. J. B. de Carvalho \& E. L. A. Monteiro-Filho. 1997. A preliminary analysis of insects of medical-legal importance in Curitiba, state of Paraná. Memórias do Instituto Oswaldo Cruz 92: 269-274.

Nabity, P. D.; L. G. Higley \& T. M. Heng-Moss. 2007. Light-Induced variability of forensically important blow fly Phormia regina (Diptera: Calliphoridae). Journal of Medical Entomology 44: 351-358.

Oliveira, T. C. \& S. D. Vasconcelos. 2010. Insects (Diptera) associated with cadavers at the Institute of Legal Medicine in Pernambuco, Brazil: Implications for forensic entomology. Forensic Science International 128: 97-102.

Patitucci, L. D.; P. R. Mulieri; A. Oliva \& C. Mariluis. 2010. Status of the forensically important genus Ophyra (Diptera: Muscidae) in Argentina. Revista de la Sociedad Entomológica Argentina 69: 91-99.

R Development Core Team. 2009. R: A language and environment for statistical computing. R Foundation for Statistical Computing, Vienna, Austria. Available from: http://www.R-project.org (accessed 26 November 2009)

Ribeiro, P. B.; C. J. B. de Carvalho; P. R. P. \& P. Siveira-Jr. 2000a. Desenvolvimento de Ophyra aenescens Wiedemann, 1830 (Diptera, Muscidae, Azeliinae), em diferentes temperaturas, em condições de laboratório. Revista Brasileira de Agrociência 6: 80-87.

Ribeiro, P. B.; C. J. B. de Carvalho; A. M. Chernaki \& P. R. P. Costa. 2000 b. Longevidade, oviposição e viabilidade pupal de Ophyra aenescens Wiedemann, 1830 (Diptera, Muscidae, Azeliinae), em condições de laboratório. Revista Brasileira de Agrociência 6: 264-268. 
Ribeiro, P. B.; C. J. B. de Carvalho; L. Pinto \& P. Silveira-Jr. 2000c. Flutuação populacional das espécies de Ophyra Robineau-Desvoidy (Diptera, Muscidae, Azeliinae) na região de Pelotas, RS. Arquivos do Instituto Biológico 67: 205-214.

Ribeiro, P. B.; C. J. B. de Carvalho; M. Regis \& P. R. P. Costa. 2001. Exigências térmicas e estimativa do número de gerações de Ophyra aenescens Wiedemann, 1830 (Diptera, Muscidae, Azeliinae), em Pelotas, RS. Arquivos do Instituto Biológico 68: 75-82.

Richards, C. S. \& M. H. Villet. 2008. Factors affecting accuracy and precision of thermal summation models of insect development used to estimate post-mortem intervals. International Journal of Legal Medicine 122: 401-408

Rosa, T. A.; M. L. Babata; C. M.de Souza; D. de; C. A. de Mello-Patiu \& J. Mendes. 2009. Dípteros de interesse forense em dois perfis de vegetação de cerrado em Uberlândia, MG. Neotropical Entomology 38: 859-866.

Segura, N. A.; W. Usaquén; M. C. Sánchez; L. Chuaire \& F. Bello. 2009. Succession pattern of cadaverous entomofauna in a semi-rural area of Bogotá, Colombia. Forensic Science International 187: 66-72.
Skidmore, P. 1985. The Biology of the Muscidae of the world. Dordecht, Kunk Publisheis, 550 p.

Smith, K. G. V. 1986. A Manual of Forensic Entomology. London, British Museum of Natural History, $205 \mathrm{p}$

Souza, A. S. B.; F. D. Kirst \& R. F. Krüger. 2008. Insects of forensic importance from Rio Grande do Sul state in Southern Brazil. Revista Brasileira de Entomologia 52: 641-646.

Tachibana, S. I. \& H. Numata. 2004. Effects of temperature and photoperiod on the determination of larval diapause in Lucilia sericata (Diptera: Calliphoridae). Zoological Science 21: 197-202.

Wells, J. D. \& N. L. LaMotte. 2010. Estimating the postmortem interval, p. 367-388. In: Byrd, J. H. \& J. L. Castner (Eds.). Forensic Entomology: The Utility of Arthropods in Legal Investigations. 2nd edition, Boca Raton, CRC Press, $681 \mathrm{p}$.

Zimmer, C. R.; S. M. Pires; M. C. Cárcamo \& P. B. Ribeiro. 2010. Comportamento de propagação radial de Muscina stabulans (Fallén) (Diptera: Muscidae) em condições de laboratório. Neotropical Entomology 39: 194-197. 